Reprinted with permission from: Weed Technology. 1998. 12(2):367-373.

Published and copyrighted by: Weed Science Society of America. http://www.wssa.net

\title{
The biology and integrated management of leafy spurge (Euphorbia esula) on North Dakota rangeland ${ }^{1}$
}

\author{
RODNEY G. LYM
}

Professor, Plant Science Deprartment, North Dakota State University, Fargo, ND 58105.

\begin{abstract}
:
Leafy spurge, a long-lived perennial, grows in many habitats, from floodplains to grasslands and mountain slopes. The plant emerges in early spring and produces showy, yellow bracts that appear in late May. The true flowers emerge in mid-June. The plant spreads by both seeds and roots and contains a white sticky latex that deters grazing by many animals. Dicamba, 2,4-D, glyphosate, and picloram have commonly been used to control leafy spurge. Picloram plus 2,4-D is frequently used for leafy spurge control in North Dakota. Ten insect species for leafy spurge biocontrol have been released in North Dakota; the most successful have been the flea beetles, Aphthona nigriscutis, A. czwalinae, and A. lacertosa. The leafy spurge gall midge (Spurgia esulae) has been most successful near wooded areas. Herbicides combined with either the leafy spurge flea beetles or gal midge have controlled leafy spurge better than either method used alone. Grazing with sheep or goats is a cost-effective method for controlling leafy spurge top growth in large infestations. Grazing combined with fall-applied picloram plus 2,4-D reduced leafy spurge density more rapidly and maintained control longer than either method used alone. Several grass species are competitive with leafy spurge including 'Rebound' smooth brome, 'Rodan' western wheatgrass, 'Pryor' slender wheatgrass, and 'Manska' pubescent wheatgrass. Cultivating twice each fall after harvest for 3 years in cropland completely controlled leafy spurge. A successful long-term management program should be designed for specific situations and should include combinations of herbicides, insects, grazing, and/or seeding competitive species.
\end{abstract}

\footnotetext{
${ }^{1}$ Received for publication June 27, 1997, and in revised form February 12, 1998.
} 


\section{Nomenclature:}

2,4-D, (2,4-dichlorophenoxy) acetic acid; dicamba, (3,6-dichloro-2methoxybenzoic acid); glyphosate, N-(phosphonomethyl)glycine; picloram, (4-amino-3,5,6-trichloro-2-pyridinecar-boxylic acid); smooth brome, Bromus inermis Leyss. 'Rebound'; western wheatgrass, Pascopyrum smithii Rydb. 'Rodan'; slender wheatgrass Elymus trachycaulus ssp. trachycaulus (Link) Gould ex Shinners 'Pryor'; pubescent wheatgrass Elytrigia intermedia (Host) Nevski 'Manska'; leafy spurge gall midge, Spurgia esulae; leafy spurge, Euphorbia esula L. \#² EPHES.

\section{Additional index words:}

Noxious weed, biocontrol, integrated pest management, grazing, cultural, chemical, EPHES.

\section{Abbreviations:}

MAT, months after treatment.

\section{Introduction}

Leafy spurge grows on a wide variety of terrains, from floodplains to riverbanks, grasslands, ridges, and mountain slopes (Hanson and Rudd 1933). It is found primarily in untilled noncropland habitats such as abandoned cropland, pastures, rangeland, woodland, roadsides, and waste areas (Dunn 1979, 1985; Selleck et al. 1962). The plant grows in diverse environments from dry to subhumid and from subtropic to subarctic. It occurs on many topographic positions, from the flat bottom of glacial lakes to the slopes of sand dunes and glacial moraines. Herbage production is decreased by as much as $75 \%$ when leafy spurge infests pasture and rangeland (Lym and Messersmith 1985; Reilly and Kaufman 1979). Once leafy spurge is introduced into a new area, topography does not seem to limit its spread.

Traditionally, herbicides have been used to control leafy spurge in North Dakota and have been relatively successful following a long-term program. However, herbicides may not be acceptable due to their high cost, potential for groundwater contamination, and prohibition in environmentally sensitive areas. Consequently, nonchemical methods for control have been developed.

Nonchemical methods for leafy spurge management include mechanical control, seeding with competitive grasses, grazing, and the use of biocontrol insects. The use of pathogens as biological control agents of leafy spurge has been evaluated since the early

\footnotetext{
${ }^{2}$ Letters following this symbol are a WSSA-approved computer code from Composite List of Weeds, Revised 1989. Available from WSSA, 810 East $10^{\text {th }}$ Street, Lawrence, KS 66044-8897.
} 
1980s, but to date has not been successful. The purpose of this review is to outline the chemical, biological, and cultural control methods alone and in combination currently available for leafy spurge control. Although much of the data presented are from North Dakota, the management techniques are applicable throughout much of the leafy spurge infestations in North America.

\section{Leafy spurge biology}

Leafy spurge is a dicotyledonous, herbaceous, deep-rooted perennial. Messersmith et al. (1985) have extensively reviewed the biology of this plant. Leafy spurge is one of the first plants to emerge in the spring. It generally emerges in March in Iowa (Bakke 1936), early April in North Dakota (Hanson and Rudd 1933), and by May 1 in Saskatchewan (Selleck et al. 1962). The early and rapid growth gives leafy spurge a competitive advantage over native range plants.

Leafy spurge normally grows about $1 \mathrm{~m}$ tall from a woody crown (Hanson and Rudd 1933; Selleck et al. 1962). Each crown area produces several upright stems. The plant bears numerous linear-shaped leaves with smooth margins. Leafy spurge leaves have a characteristic bluish-green appearance. The most conspicuous feature of leafy spurge is the yellowish-green flowerlike clusters. The inflorescence is borne on an umbel at the tip of the stem or on lateral branches near the tip. The true flower parts are surrounded by cuplike bracts (involucre) of the cyathium. Yellowish-green bracts appear 2 to 3 weeks before the true flower parts. The distinction between bract appearance and true flowering is important for timing of herbicide applications.

Seeds are borne in pods that contain three gray-brown, oblong seeds (Hanson and Rudd 1933; Krockmal 1952). An average of 140 seeds are produced per stem, and seeds may remain viable in the soil at least 8 years (Wicks and Derscheid 1964). Seeds go through several color changes during development, from yellow through orange and brown to gray at maturity. Leafy spurge control must be done before seeds have turned brown to prevent viable seed production (Selleck et al. 1962; Wicks and Derscheid 1964).

The peak period for leafy spurge seed germination is late spring, but seeds can germinate throughout the growing season (Selleck et al. 1962). Seedlings develop rapidly after emergence and mature quickly. Vegetative reproduction of leafy spurge by root buds can occur within 7 to 10 days after emergence.

Successful leafy spurge control requires killing the root system and associated vegetative buds (Hanson and Rudd 1933). The roots are woody and durable in structure, with numerous buds capable of producing new shoots at numerous points along any root segment. Roots are most abundant in the upper $12 \mathrm{~cm}$ of soil, but some roots can extend as deep as the water table (Hanson and Rudd 1933). The root system contains a large nutrient reserve capable of sustaining the plant for years (Lym and Messersmith 1987a).

Latex is present throughout the plant from root to shoot (Bakke 1936). Injury to any part of the plant will result in immediate flow of the white, sticky latex to seal the wound. Leafy spurge latex contains a highly irritant and inflammatory compound called ingenol 
(Seip and Hecker 1982; Upadhyay et al. 1978) that, when taken internally, is an irritant, emetic, and purgative to most species (Bakke 1936). Latex causes scours and weakness in cattle and may result in death (Selleck et al. 1962). Animals will eat dried leafy spurge in hay, but some livestock, particularly cattle, avoid eating growing plants.

Leafy spurge spreads by both seeds and roots. Man, wild and domestic animals, birds, insects, and water are agents of leafy spurge seed dissemination (Messersmith et al. 1985). Approximately $1 \%$ of the seeds will germinate successfully and become established as vegetative seedlings (Bowes and Thomas 1978a). Once established, leafy spurge spreads rapidly by roots. Roots of a single plant can spread up to $5 \mathrm{~m}$ in diameter per year (Selleck et al. 1962) and will inhabit 0.4 ha in 65 years with over 250,000 stems (Stroh et al. 1990). Small patches $(<8 \mathrm{~m})$ expand at rates up to 500 times faster than larger patches, which highlights the need to regularly survey and control small patches as they appear.

\section{Control with herbicides}

Leafy spurge is difficult to eradicate, but top growth control and a gradual decrease in the underground root system are possible with a persistent management program. Most experimental herbicides have been screened for leafy spurge control since the introduction of 2,4-D in the 1940s (Alley et al. 1984; Lym and Messersmith 1985). Most of these herbicides have little or no activity on leafy spurge.

Herbicides commonly used to control leafy spurge include 2,4-D, dicamba, glyphosate, and picloram (Lym and Messersmith 1985). Even though glyphosate is a nonselective herbicide, leafy spurge control from glyphosate plus $2,4-\mathrm{D}$ averages $75 \%$ or better 12 months after treatment (MAT) with 0 to $10 \%$ grass injury. The 2,4-D causes reduced grass control from the glyphosate but at the same time enhances leafy spurge control. Dichlobenil (2,6-dichlorobenzonitrile) only suppresses leafy spurge growth but can be used under trees (Lym and Messersmith 1982). Fosamine [ethyl hydrogen (aminocarbonyl)phosphonate] can be used adjacent to water (Lym and Messersmith 1988).

Proper timing of herbicide application is essential for good leafy spurge control (Lym and Messersmith 1985). Leafy spurge is most susceptible to 2,4-D, dicamba, or picloram applied when the plant is in the true flower growth stage or in early to mid-September after the stems have developed new fall regrowth. Glyphosate plus 2,4-D provides good leafy spurge control when applied during seed set in late June or early July (Lym 1996) but can cause severe grass injury when fall applied.

Long-term control of leafy spurge is extremely difficult to achieve. The most costeffective control method depends on the size and location of the infested area. Small patches of leafy spurge can be eliminated with a persistent herbicide program, but large areas will require additional control measures. A combination of chemical treatments with biological or cultural control practices such as cultivation, cropping, and grazing is necessary to control and stop the spread of leafy spurge, especially when it infests large acreages (Alley et al. 1984; Dersheid et al. 1985; Sedivec and Maine 1993). 
Picloram and 2,4-D are the most frequently used herbicides for leafy spurge control in North Dakota. Picloram reduces leafy spurge density more effectively, but 2,4-D controls the leafy spurge foliage at the lowest cost. Both herbicides are poorly absorbed (generally less than $30 \%$ ), and $5 \%$ or less of the absorbed herbicide is translocated to the roots (Lym and Moxness 1989).

The most widely used treatment for both leafy spurge control and improved forage production is picloram plus 2,4-D at 0.28 plus $1.1 \mathrm{~kg} / \mathrm{ha}$ (Lym and Messersmith 1990). About 93,000 ha in North Dakota are treated with picloram plus 2,4-D annually to control leafy spurge. Picloram plus 2,4-D at 0.28 plus $1.1 \mathrm{~kg} / \mathrm{ha}$ costs about $\$ 30 / \mathrm{ha}$ and requires annual application for 3 to 5 years to obtain approximately $90 \%$ control (Lym and Messersmith 1987b).

Glyphosate plus 2,4-D at 0.45 plus $0.65 \mathrm{~kg}$ /ha will control 65 to $70 \%$ of leafy spurge 12 MAT, while picloram plus 2,4-D averages only 40\% control (Lym 1996). The treatment costs approximately $\$ 12$ to $\$ 15 /$ ha less than picloram plus $2,4-\mathrm{D}$ at 0.28 plus 1.1 $\mathrm{kg} / \mathrm{ha}$ and can be used in areas with a high water table. Glyphosate plus 2,4-D should not be applied to the same area for 2 consecutive years as severe grass injury may occur.

AC 263,222 (Lym 1997) and quinclorac (3,7-dichloro-8-quinolinecarboxylic acid) are two new herbicides that provide good leafy spurge control when fall applied (Lym et al. 1997a). AC 263,222, which currently is labeled for use on noncropland and highway rights of way only, provides similar to or better control than picloram plus 2,4-D and costs approximately $\$ 40 /$ ha.

Quinclorac provides similar control to picloram plus 2,4-D and has two very desirable attributes (Lym et al. 1997a). In a regional research project involving six states, quinclorac did not injure desirable forage grasses at any location. Also, the researchers noted that quinclorac did not injure many desirable broadleaf species including lead plant (Amorpha canescens Pursh), purple prairie clover (Dalea purpurea Vent.), prairie wild rose (Rosa arkansana Porter), willow (Salix spp.), and wild raspberry (Rubus spp.). Unfortunately, quinclorac is not yet labeled for leafy spurge control.

Leafy spurge control with herbicides is not always practical due to the high cost of treating large areas of infestation, especially because the economic return is low on range and untilled land. Also, the weed frequently occurs in environmentally sensitive areas where herbicide use is prohibited. Thus, biological control agents and/or cultural control methods may offer the best solution for control on a large scale and in the diverse environments where leafy spurge grows.

\section{Integrated biological control}

A major program for leafy spurge biocontrol was initiated across the United States in the 1980s. Since then, 10 insects for biological control of leafy spurge have been released in North Dakota (Carlson and Mundal 1990). The spurge hawkmoth (Hyles euphorbiae L.), a foliar feeder, generally has not survived, and when it did survive, control was too late in the growing season to be very useful (Messersmith and Lym 1990). Six rootfeeding flea beetles, Aphthona cyparissiae Koch, A. flava Guillebeau, A. czwalinae Weise, A. 
lacertosa Rosenhauer, A. abdominalis Duftschmid, and A. nigriscutis Foudras, and a gall midge, Spurgia esulae Gagne, have been established at several research sites in the state and region. A stem-boring beetle, Oberea erythrocephala Shrank, has been released and established at two locations in North Dakota but not in sufficient numbers to allow redistribution.

The Aphthona spp. have provided the greatest control of leafy spurge because the larvae feed on the root system, the population has increased rapidly since introduction, and the adult insects are easily captured for transport to additional locations. A. nigriscutis originally was the most successful Aphthona spp. to establish in the region (R. B. Carlson, personal communication). However, beginning in 1994, a mixed population of $A$. czwalinae and A. lacertosa began to reproduce rapidly. Over 1, 25, and 6 million of the mixed population beetles were redistributed to various states and Canada in 1994, 1995, and 1996, respectively. Both A. nigriscutis and A. czwalinae/A. lacertosa have been redistributed to all 52 North Dakota counties.

Although Aphthona spp. are well established at many sites, leafy spurge control by Aphthona spp. has been slow. Populations must be high enough that several larvae feed on each root and the adult insects do not move rapidly from the center of establishment (R. B. Carlson, personal communication). Also, an unexpected finding of current research is that herbage production has not returned to normal even after leafy spurge density has been reduced by Aphthona spp. feeding for several years (Kirby 1996). For example, Kirby (1996) found leafy spurge density was reduced three- to fivefold at two locations in North Dakota 5 years after the initial flea beetle release, but little or no increase in graminoid production compared to the control was observed. The reason for the lack of response by the graminoid species is not known. Perhaps the leafy spurge root system is still competing with the grass species for nutrients and moisture and/or releasing growthinhibiting compounds.

Even though the flea beetles have become established at locations throughout the state and region, the success rate in some areas is very low to zero. For example, in a USDA study, only 14 of 34 A. nigriscutis releases in 1991 established (Rees 1994). Also, none of 10 releases made in the North Dakota Sheyenne National Grasslands from 1991 through 1993 established. Five species of Aphthona were released, and the number of flea beetles released per site ranged from 150 to $1,350 /$ plot. This implies that the local environment inhibited establishment, not the number or species of Aphthona released. The Sheyenne National Grasslands has both very dense leafy spurge infestations and a very sandy $(>80 \%)$ soil.

In a second example, A. nigriscutis, A. czwalinae, and A. lacertosa were released at two separate North Dakota State University research locations 25 miles apart on the same dates. All species established at one location and none at the other (R. G. Lym, unpublished data). The major difference between the two locations was the amount of sand in the soil. Where the insects established, the soil had $45 \%$ sand, but the nonestablishment site averaged $85 \%$ sand.

Reasons for nonestablishment include severe weather immediately after release, reduced beetle vigor from too long in transit or improper storage during transit, and collection too late in the season for effective egg laying (Rees 1994). These detriments can 
partially be overcome by education of land managers and experience with flea beetles. However, release of flea beetles in very dense leafy spurge $\left(>320\right.$ stems $/ \mathrm{m}^{2}$ ) and/or where the weed is growing in very sandy $(>80 \%)$ soil reduces the probability of establishment and subsequent weed control. Leafy spurge grows very well in high sand soils, where it infests thousands of hectares in the Northern Great Plains. If biological control agents cannot be established in these areas, then a significant portion of the Northern Great Plains will likely see a continued expansion of this weed.

Since Aphthona spp. apparently will establish in only limited numbers in some areas, other control methods need to be incorporated with the biocontrol agents to successfully control leafy spurge in a variety of environments. Herbicides have been successfully combined with both the Aphthona spp. and Spurgia esulae biological control agents. Treatments with herbicides combined with either of these biocontrol agents have resulted in a greater leafy spurge density reduction than either method used alone. For example, dramatic increases in biological control agent population and subsequent leafy spurge control have been observed in the field when herbicides were combined with Aphthona spp. flea beetles (Lym et al. 1996). The leafy spurge stand declined from $82 \mathrm{stems} / \mathrm{m}^{2}$ before treatment to $12 \mathrm{stems} / \mathrm{m}^{2}$ during the next growing season after the herbicide treatment picloram plus 2,4-D at 0.56 plus $1.1 \mathrm{~kg} / \mathrm{ha}$ had been applied in the fall to leafy spurge infested with A. nigriscutis. The leafy spurge density gradually declined when only insects were present and took 3 years longer to reduce the infestation to the same level achieved in 1 year by the herbicide-plus-insect combination treatment.

The $S$. esulae gall midge causes stem tip galls on leafy spurge, thereby decreasing seed production. It has been most successful near wooded areas (R. B. Carlson, personal communication). However, a second control method was needed to reduce the original leafy spurge infestation and to prevent spread from roots. Imazethapyr, picloram, and 2,4-D applied outside the tree dripline reduced the leafy spurge stand, but did not affect the $S$. esulae population as long as 15 to $25 \%$ of the leafy spurge-infested area was left untreated by herbicides (Lym and Carlson 1994). This combination treatment has been adopted by land managers to reduce leafy spurge seed production in wooded areas where Aphthona spp. have not established well.

\section{Integrated control with grazing}

When leafy spurge infests large acreages, grazing with sheep (Ovis spp.) or goats (Capra spp.) may be the only cost-effective treatment option for controlling leafy spurge top growth in pasture and rangeland (Olson and Lacey 1994; Sedivec and Maine 1993). Leafy spurge stand density may gradually be reduced, and the landowner can recover some control costs from sale of the animals. However, even when grazing is the only control method used, the perimeter of the infestation should be treated with herbicides to prevent further spread.

Grazing should be started early in the spring when leafy spurge first emerges (Landgraf et al. 1984). On large infestations, pastures should be divided so animals can be regularly rotated and the entire infestation grazed in a timely manner. Goats increased in popularity as biological control agents for leafy spurge in the northern Great Plains in the mid-1980s 
and 1990s (Hanson 1994; Olson and Lacey 1994). Sheep were effective for controlling leafy spurge top growth in the 1930s (Helgeson and Longwell 1942) but have been little utilized. Grazing with goats may be preferred over sheep by cattle ranchers because the dietary overlap of sheep and cattle averaged 20 to $35 \%$ compared to only 5 to $20 \%$ with goats (Olsen and Hansen 1977). Also, goats effectively graze leafy spurge regardless of plant density, while leafy spurge consumption by sheep declines as plant density increases (Walker et al. 1994). Which animal to utilize will depend on a land manager's specific conditions (cost of fencing, predator control, need to overwinter, etc.) and the marketability of the animals.

Grazing with angora goats for 2 to 3 years reduced leafy spurge cover by 55 to $85 \%$ in North Dakota (Sedivec et al. 1995). Although stem densities and cover were reduced, no studies have shown that grazing with goats will kill leafy spurge (Olson and Lacey 1994). As with other control methods, once the animals were removed, leafy spurge began to regrow to its original densities. Eight years of intensive grazing by sheep nearly eliminated the leafy spurge top growth, but the plants began regrowing from the roots 1 years following the removal of the sheep and quickly reestablished (Bowes and Thomas 1978b).

Grazing with goats has also been integrated with herbicide treatments for leafy spurge control. Grazing with goats alone reduced the infestation enough to allow cattle grazing, but only as long as the goat grazing continued indefinitely. However, goat grazing combined with a fall-applied herbicide treatment such as picloram plus 2,4-D reduced leafy spurge density more rapidly and maintained control longer than either method used alone (Lym et al. 1997b). These treatments reduced leafy spurge density by $98 \%$, from an aver-

age of $64 \mathrm{stems} / \mathrm{m}^{2}$ to one stem $/ \mathrm{m}^{2}$ in 3 years and maintained that level of control for at least two seasons after the last treatments.

\section{Cultural control with grass competition or cultivation}

Cultural control of leafy spurge includes properly timed cultivation and/or planting of competitive grass species. Cultural methods that control only leafy spurge top growth include mowing and fire. All cultural control methods are more successful when combined with herbicide treatments than when used alone.

Some perennial grass species effectively compete to provide leafy spurge control. 'Bozoisky' Russian wildrye [Psathyrostachys juncea (Fisch.) Nevski] and 'Luna' pubescent wheatgrass [Elytrigia intermedia (Host) Beauv.] planted into a dense leafy spurge stand in Wyoming reduced leafy spurge biomass by more than $90 \%$ for at least 4 years (Whitson et al. 1990). Several grass species competed well with leafy spurge on both clay and loamy sand soils in North Dakota (Lym and Tober 1997). Rebound smooth brome, Rodan western wheatgrass, Pryor slender wheatgrass, and Manska pubescent wheatgrass all provided an average of $85 \%$ leafy spurge control for at least $3 \mathrm{yr}$. Not only were the grasses very competitive with leafy spurge, but they also provided high yields and good nutritive value for grazing. Grazing following grass establishment should be limited and conducted at the proper growth stage of the grasses or leafy spurge will rapidly reinfest the seeded area (T. Whitson, personal communication). 
The options for control of leafy spurge established in cropland are limited, because the herbicide rates required for control are greater than are labeled for use in cropland (Lym and Messersmith 1990). During a 6-yr experiment in North Dakota, perennial weeds did not establish in a conventional-tillage system but appeared within 2 years in both reduced- and no-till systems (Miller and Nalewaja 1985).

Cultivating twice each fall after harvest for 3 years completely controlled leafy spurge in North Dakota (Lym and Messersmith 1993). Cultivation followed by nitrogen application reduced the stand by $85 \%$, whereas nitrogen applied alone had little effect. Cultivation combined with an herbicide treatment will eliminate leafy spurge from cropland more rapidly than cultivation alone. Because cultivation does not need to be intensive over an entire growing season, a crop can be produced on the land.

\section{Best control option}

An integrated control program combining two or more methods will provide a more successful and cost-effective long-term solution to the leafy spurge problem than a single method used alone. Biological control with insects or control with grazing has been improved when combined with fall-applied herbicides. The key to controlling leafy spurge is early detection and treatment of the initial invading plant. A persistent management program is needed to control top growth and to gradually deplete the nutrient reserves in the root system. The program should be designed for specific situations. An integrated system that controls leafy spurge well in the sandy soils of the Sheyenne National Grasslands in eastern North Dakota will not necessarily be the best program for the rocky soils in the western North Dakota Badlands.

\section{Literature cited}

Alley, H. P, N. E. Humburg, J. K. Fornstrom, and M. Ferrell. 1984. Leafy spurge control with repetitive herbicide treatments. Res. Weed Sci., Wyo. Agric. Exp. Stn. Res. J. 192:90-93.

Bakke, A. L. 1936. Leafy Spurge, Euphorbia esula L. Iowa Agricultural Experiment Station Research Bull. 198. $38 \mathrm{p}$.

Bowes, G. C. and A. G. Thomas. 1978a. Leafy spurge (Euphorbia esula L.) control based on a population model. Proc. First Int. Rangeland Congr. 1:254-256.

Bowes, G. C. and A. G. Thomas. 1978b. Longevity of spurge seeds in soil following various control programs. J. Range Manage. 31:137-140.

Carlson, R. B. and D. Mundal. 1990. Introduction of insects for the biological control of leafy spurge in North Dakota. N. D. Farm Res. 47:7-8.

Dersheid, L. A., L. J. Wrage, and W. E, Arnold. 1985. Cultural control of leafy spurge. In A. K. Watson, ed. Leafy Spurge. Monogr. 3. Champaign, IL: Weed Science Society of America. pp. 57-64.

Dunn, P. H. 1979. The distribution of leafy spurge (Euphorbia esula) and other weedy Euphorbia spp. in the United States. Weed Sci. 27:509-516.

Dunn, P. H. 1985. Origins of leafy spurge in North America. In A. K. Watson, ed. Leafy Spurge. Monogr. 3. Champaign, IL: Weed Science Society of America 7-13.

Page 9 of 11 
Hanson, H. C. and V. E. Rudd. 1933. Leafy Spurge Life History and Habits. North Dakota Agricultural Experiment Station Bull. 266. pp. 1-24.

Hanson, T. P. 1994. Leafy Spurge (Euphorbia esula L.) Control, Using Angora Goats. M.S. thesis. North Dakota State University, Fargo, ND. 111 p.

Helgeson, E. A. and J. H. Longwell. 1942. Control of leafy spurge by sheep. N. D. Agric. Exp. Stn. Bimonthly Bull. 4:10-12.

Kirby, D. 1996. Biological control of leafy spurge (Euphorbia esula) with flea beetles (Aphthona spp.). Abstr. Soc. Range Manage. 49:40.

Krockmal, A. 1952. Seeds of weedy Euphorbia species and their identification. Weeds 1:243-255.

Landgraf, B. K., P. K. Fay, and K. M. Havstad. 1984. Utilization of leafy spurge (Euphorbia esula) by sheep. Weed Sci. 32:348-352.

Lym, R. G. 1996. Leafy Spurge Control with Glyphosate Plus 2,4-Alternated with Picloram or Dicamba. Research Progress Report of the Western Society of Weed Science. p. 7.

Lym, R. G. 1997. Imazameth for Leafy Spurge Control. Research Progress Report of the Western Society of Weed Science. p. 8.

Lym, R. G., K. G. Beck, R. Becker, E. Davis, M. A. Ferrell, J. Harris, and R. Masters. 1997a. Leafy Spurge Control with Quinclorac, a Regional Study. Research Progress Report of the Western Society of Weed Science. pp. 12-14.

Lym, R. G. and R. B. Carlson. 1994. Effect of herbicide treatment on leafy spurge gall midge (Spurgia esulae) population. Weed Technol. 8:285-288.

Lym, R. G., R. B. Carlson, C. G. Messersmith, and D. A. Mundal. 1996. Integration of herbicides with flea beetles, Aphthona nigriscutis, for leafy spurge control. In Proceedings of the IX International Symposium on Biological Control of Weeds. pp. 480-481.

Lym, R. G. and C. G. Messersmith. 1982. Leafy spurge control under trees with various herbicides. Proc. N. Cent. Weed Control Conf. 39:66-67.

Lym, R. G. and C. G. Messersmith. 1985. Leafy spurge control with herbicides in North Dakota: 20-year summary. J. Range Manage. 38:149-154.

Lym, R. G. and C. G. Messersmith. 1987a. Carbohydrates in leafy spurge roots as influenced by environment. J. Range Manage. 40:139-144.

Lym, R. G. and C. G. Messersmith. 1987b. Leafy spurge control and herbicide residue from annual picloram and 2,4-D application. J. Range Manage. 40:194-198.

Lym, R. G. and C. G. Messersmith. 1988. Leafy spurge control under trees and along waterways. Res. Rep. N. Cent. Weed Control Conf. 45:86-87.

Lym, R. G. and C. G. Messersmith. 1990. Cost-effective long-term leafy spurge (Euphorbia esula) control with herbicides. Weed Technol. 4:635-641.

Lym, R. G. and C. G. Messersmith. 1993. Fall cultivation and fertilization reduce winter hardiness of leafy spurge (Euphorbia esula). Weed Sci. 41:441-446.

Lym, R. G. and K. D. Moxness. 1989. Absorption, translocation, and metabolism of picloram and 2,4-D in leafy spurge (Euphorbia esula). Weed Sci. 37:498-502.

Lym, R. G., K. K. Sedivec, and D. R. Kirby. 1997b. Leafy spurge control with Angora goats and herbicides. J. Range Manage. 50:123-128.

Lym, R. G. and D. A. Tober. 1997. Competitive grasses for leafy spurge (Euphorbia esula) reduction. Weed Technol. 11:787-792.

Messersmith, C. G. and R. G. Lym. 1990. Leafy spurge control: 10 years of research enhancement. N. D. Farm Res. 47:3-6.

Page 10 of 11 
Messersmith, C. G., R. G. Lym, and D. S. Galitz. 1985. Biology of leafy spurge. In A. K. Watson, ed. Leafy Spurge. Monogr. 3. Champaign, IL: Weed Science Society of America. pp. 42-56.

Miller, S. D. and J. D. Nalewaja. 1985. Weed spectrum change and control in reduced-till wheat. N. D. Farm Res. 43:11-14.

Olsen, E W. and R. M. Hansen. 1977. Food relations of wild free-roaming horses, livestock, and big game, Red Desert, Wyoming. J. Range Manage. 30:17-20.

Olson, B. E. and J. R. Lacey. 1994. Sheep: a method for controlling rangeland weeds. Sheep Res. J. Special issue. pp. 105-112.

Rees, N. E. 1994. The Aphthona pilot study. In Proceedings of the Leafy Spurge Symposium. Bozeman, MT. U.S. Department of Agriculture-Agricultural Research Service. 45 p.

Reilly, W. and K. R. Kaufman. 1979. The social and economic impacts of leafy spurge in Montana. In Proceedings of the Leafy Spurge Symposium. Fargo, ND: North Dakota Cooperative Extension Service. pp. 21-24.

Sedivec, K. K., W. T. Barker, and C. W. Prosser. 1995. Intensive grazing of angora goats on leafy spurge infested land. In D. S. Galitz, ed. Proceedings of the Leafy Spurge Symposium. Fargo, ND: North Dakota State University. pp. 34-36.

Sedivec, K. K. and R. P. Maine. 1993. Angora goat grazing as a biological control for leafy spurge: a three year summary. In K. G. Beck, ed. Proceedings of the Leafy Spurge Symposium. Fort Collins, CO: Colorado State University. pp. 1-5.

Seip, E. H. and E. Hecker. 1982. Skin irritant ingenol esters from Euphorbia esula. J. Med. Plant Res. 46:215-218.

Selleck, G. W, R. T Coupland, and C. Frankton. 1962. Leafy spurge in Saskatchewan. Ecol. Monogr. 32:129.

Stroh, R. K., J. A. Leitch, and D. A. Bangsund. 1990. Leafy spurge patch expansion. N. D. Farm Res. 47:15-27.

Upadhyay, R. R., E Bakhtavar, M. Ghaisarzadeh, and J. Tilabi. 1978. Cocarcinogenic and irritant factors of Euphorbia esula. 1. Latex. Tumori 64: 99-102.

Walker, J. W, S. L. Kronberg, S. L. Al-Rowaily, and N. E. West. 1994. Comparison of sheep and goat preferences for leafy spurge. J. Range Manage. 47:429-434.

Whitson, T D., D. W. Koch, A. E. Gade, and M. A. Ferrell. 1990. Control of leafy spurge (Euphorbia esula) by the integration of herbicides and perennial grass species. Weed Sci. Soc. Am. Abstr. 30:31.

Wicks, G. A. and L. A. Derscheid. 1964. Leafy spurge seed maturation. Weeds 12:175-176. 